Joanna PIETRZAK-ZAWADKA

Sebastian JUSZKO

Tomasz KUĆ

Radosław LEWOŃ

Michał OSTROWSKI

Justyna ROGALSKA

Paweł ZALEWSKI

Zamiejscowy Wydziat Leśny Politechniki Biatostockiej

\title{
DRZEWA-POMNIKI PRZYRODY NA TERENIE SUWALSKIEGO PARKU KRAJOBRAZOWEGO
}

\section{Wstęp}

Przesłankami do ochrony drzew były głównie poglądy religijne, wierzenia i obyczaje naszych przodków. Okazy te traktowano z wielkim szacunkiem i otaczano opieką. Z czasem tego typu obiekty przyrodnicze, wyróżniające się spośród innych szczególnymi cechami, objęto regulacjami prawnymi w zakresie ich szczególnej ochrony.

Cenne drzewa, podobnie jak ekosystemy i siedliska, mogą być narażone na wiele czynników stresujących, wynikających w głównej mierze z działalności lub - ogólnie - bytności człowieka. Obecnie wzrost świadomości ekologicznej wśród ludności jest głównym czynnikiem decydującym o ochronie okazałych drzew na danym obszarze. Ważnym zagadnieniem jest rozróżnienie i popularyzacja okazów wyróżniających się.

Pomnik przyrody jest kategorią prawną, oznaczającą objęcie tworu przyrody ochroną prawną, z określonymi konsekwencjami za jej nieprzestrzeganie. Istotą tej ochrony jest wyłączenie chronionej rośliny spod oddziaływania człowieka w sensie jej gospodarczego użytkowania. Jest to jednoznaczne z nadaniem drzewu statusu nienaruszalności (Siewniak, 1998). Zapewnienie tego statusu nosi znamiona ochrony biernej i jest dla 
drzew-pomników przyrody niewystarczającą formą ochrony. Pomnikowym drzewom należy bowiem zapewnić stałą, aktywną, szeroką i systematyczną pielęgnację. $W$ trudnych warunkach środowiskowych drzewa te wymagają dodatkowo ograniczenia do minimum wszelkiego potencjalnego wpływu czynników szkodliwych. Dzięki prawidłowej pielęgnacji takie okazy pomnikowe doznały wsparcia i znajdują się we względnie dobrym stanie. Jednocześnie $w$ warunkach miejskich czy na terenach komunikacyjnych na zarządzających tym zasobem spoczywa obowiązek zapewnienia maksymalnego bezpieczeństwa życiu i mieniu ludzi. Utrzymanie pomnika przyrody oznacza zachowanie drzewa w całości i zapewnienie mu koniecznych warunków siedliskowych (Siewniak, 1998). W tej sytuacji wyodrębnia się grupa drzew szczególnie cennych historycznie i kulturowo. Są one najczęściej najstarsze i w dość złym, a nieraz wręcz resztkowym, stanie. Od kilkudziesięciu lat określa się takie drzewa mianem "weteranów", zamiennie nazywa się je też matuzalemami, patriarchami, drzewami starymi, a na Litwie - baublisami (Grzywacz, Pietrzak, 2013; Kacprzak, 2005; Siewniak, 1998).

Wprowadzenie ochrony w postaci pomników przyrody ożywionej i nieożywionej powinno istotnie przeciwdziałać przynajmniej części tych zagrożeń, jak np. gospodarczemu pozyskiwaniu drzew w cennym starodrzewie lub osuszaniu torfowisk albo terenów do nich przylegających, czy też wprowadzaniu gatunków obcych. Z przyrodniczego punktu widzenia drzewa jako pomniki przyrody należą do tzw. gatunków tarczowych, czyli takich, które stwarzają dogodne warunki do życia mikroorganizmów, grzybów, roślin i zwierząt. Uważa się, że jedno drzewo może stwarzać szanse życia dla 100-1000 innych gatunków organizmów (Constaza, 1997; Grzywacz, 2001; Kacprzak, 2011; Korczyński, 2004).

Drzewa-pomniki przyrody są okazami, poprzez które chroni się przyrodę i dokumentuje różnorodność środowiska. Stanowią one jednocześnie obiekty, w których zachowały się elementy świadczące o minionych czasach, sposobach kształtowania krajobrazu (np. aleje przydrożne) i historii (m.in. szeroko rozumiane zabytki). Uznaje się, że wątek kulturowy postrzegania drzewa ma wiele wymiarów, m.in.: efekty hodowlane, aklimatyzacyjne, kunszt formowania drzewa, symbolika drzew, a wspólnym atrybutem porządku przyrodniczego i kulturowego jest czas oraz przestrzeń, w których drzewo rośnie (Grzywacz, Pietrzak, 2013; Siewniak, 1998). Pomniki przyrody to również świadectwo przeszłości zarówno człowieka, jak i środowiska (Kaszyński, Szczukowska, 2013; Korczyński, 2004). 
W Polsce wyróżnianie i rejestracja zabytkowych drzew o ponadprzeciętnym rozmiarze i pokroju ma długą historię. Tradycje ochrony niektórych drzew są związane przede wszystkim z wierzeniami i obyczajami naszych przodków. Głównym powodem podjęcia ochrony drzew był przede wszystkim szacunek, jakim je obdarzano. $Z$ czasem dochodziły do tego zapisy prawne dotyczące ochrony drzew i zakazu wycinania egzemplarzy należących do gatunków o najbardziej wartościowym drewnie. Aktualnie pomnikami przyrody są:

pojedyncze twory przyrody żywej i nieożywionej lub ich skupiska o szczególnej wartości przyrodniczej, naukowej, kulturowej, historycznej lub krajobrazowej oraz odznaczające się indywidualnymi cechami, wyróżniającymi je wśród innych tworów, okazałych rozmiarów drzewa, krzewy gatunków rodzimych lub obcych, źródła, wodospady, wywierzyska, skałki, jary, głazy narzutowe oraz jaskinie (Ustawa, 2004).

Na terenach niezabudowanych, jeżeli nie stanowi to zagrożenia dla ludzi lub mienia, drzewa będące pomnikami przyrody podlegają ochronie aż do ich samoistnego całkowitego rozpadu. Minister właściwy do spraw środowiska określa, w drodze rozporządzenia, kryteria uznawania tworów przyrody żywej i nieożywionej za pomniki przyrody, kierując się potrzebą ochrony drzew i krzewów ze względu na ich wielkość, wiek, pokrój i znaczenie historyczne, a odnośnie do tworów przyrody nieożywionej - ze względu na ich znaczenie naukowe, estetyczne i krajobrazowe.

Na terenie Polski w 2017 r. było 36510 pomników przyrody, w tym 29982 pojedynczych drzew, 3780 grup drzew oraz 762 alej, które zostały uznane za pomniki przyrody (GUS, 2017). Po 13 latach od wejścia w życie Ustawy o ochronie przyrody (2004) sporządzono i opublikowano Rozporzadzenie w sprawie kryteriów uznawania tworów przyrody żywej i nieożywionej za pomniki przyrody, co powinno być pomocne w tworzeniu nowych drzew-pomników przyrody (Rozporządzenie, 2017) (tab. 1).

Drzewa-pomniki przyrody, poza znaczeniem dla nauki, wpływają również na ocenę estetyki krajobrazu, zwiększając jego różnorodność i atrakcyjność, np. z punktu widzenia aktywności turystyczno-rekreacyjnej. Zachowanie dla następnych pokoleń starych drzew, ale również głazów narzutowych i innych obiektów przyrody nieożywionej, to głównie zachowanie tworów przyrody trwale związanych $\mathrm{z}$ krajobrazem naszego kraju (Kacprzak, 2005). Często są one związane z określonymi wydarzeniami historycznymi lub wybitnymi postaciami naszej kultury narodowej (np. dąb szypułkowy Napoleon rosnący na terenie Nadleśnictwa Przytok czy dąb szypułkowy Bażyńskiego z Kadyn). Pomniki przyrody stanowią 
prawie zawsze atrakcję turystyczną, przede wszystkim ze względu na duże znaczenie dla dydaktyki w zakresie przyrody i historii (Staniewska-Zątek, 2007).

Tab. 1. Minimalne obwody pni wybranych gatunków drzew - kandydatów na pomniki przyrody w Polsce

\begin{tabular}{|c|l|c|}
\hline Lp. & \multicolumn{1}{|c|}{ Rodzaj/gatunek drzewa } & $\begin{array}{c}\text { Minimalne obwody pni } \\
\text { wybranych gatunków } \\
\text { drzew (cm)* }\end{array}$ \\
\hline 1 & Cis pospolity & 50 \\
\hline 2 & Cyprysik, jabłon, jarząb pospolity, żywotnik zachodni & 100 \\
\hline 3 & Grusza, miłorząb, wierzba iwa, żywotnik olbrzymi & 150 \\
\hline 4 & $\begin{array}{l}\text { Brzoza brodawkowata, grab pospolity, topola osika, wiąz } \\
\text { szypułkowy }\end{array}$ & 200 \\
\hline 5 & $\begin{array}{l}\text { Jesion wyniosły, jodła pospolita, klon jawor, klon zwy- } \\
\text { czajny, modrzew, sosna zwyczajna, świerk pospolity }\end{array}$ & 250 \\
\hline 6 & $\begin{array}{l}\text { Buk pospolity, dąb bezszypułkowy, dąb szypułkowy, } \\
\text { lipa, platan, topola biała }\end{array}$ & 300 \\
\hline 7 & Inne gatunki topoli niewymienione w pkt. 4 i 6 & 350 \\
\hline
\end{tabular}

* Na wysokości $130 \mathrm{~cm}$ od powierzchni gruntu.

Źródło: Rozporządzenie... (2017).

Celem niniejszej pracy jest aktualizacja informacji o drzewach uznanych za pomniki przyrody na terenie Suwalskiego Parku Krajobrazowego oraz ukazanie możliwości wykorzystania tych okazów jako atrakcji turystycznych na tym terenie. Turystyka bowiem stwarza człowiekowi dogodne warunki do poznawania wartości, odbierania różnego rodzaju treści poznawczych i estetycznych.

\section{Materiał i metody}

Inwentaryzacji poddano drzewa uznane za pomniki przyrody na terenie Suwalskiego Parku Krajobrazowego (SPK) w październiku 2017 r. w ramach prac Koła Naukowego Leśników ZWL PB w Hajnówce.

Dla każdego okazu wykonano pomiary dendrometryczne oraz określono dokładną lokalizację drzewa uznanego za pomnik przyrody. Drzewa zostały oznaczone numerem i opisane w karcie identyfikacyjnej. Utworzono w ten sposób własną bazę danych drzew-pomników przyrody na 
badanym obszarze. Podczas badań terenowych wyróżniono kilka drzew, które pretendują do nadania im statusu ochrony prawnej $w$ postaci pomnika przyrody (tzw. drzewa - kandydaci na pomniki przyrody).

\section{Charakterystyka terenu badań}

Suwalski Park Narodowy (SPK) znajduje się na niezwykle interesującym obszarze ukształtowanym przez lądolód skandynawski. Głównym celem ochrony tego terenu jest zachowanie jego unikatowego krajobrazu. Występują tu niemal wszystkie formy ukształtowania ziemi, począwszy od moren, przez sandry, ozy, głazowiska, na rynnach subglacjalnych skończywszy (jedną z nich jest mieszczące się na terenie parku jezioro Hańcza).

Suwalski Park Krajobrazowy utworzono w 1976 r. na obszarze zagłębienia Szeszupy i terenach otaczających jezioro Hańcza w północno-wschodniej części Polski. Powierzchnia parku wynosi 6338 ha, w tym ok. 60\% stanowią użytki rolne, $10 \%$ - wody, $24 \%$ - lasy i zadrzewienia, $4 \%$ - tereny zabagnione i $2 \%$ - pozostałe grunty. Na atrakcyjność krajobrazu parku wpływa przewaga użytków rolnych. Duże, otwarte przestrzenie doskonale ukazują niezwykle bogatą rzeźbę terenu. Na terenie parku znajdują się 24 jeziora, każde o powierzchni większej od 1 ha. Cały obszar jest położony w dorzeczu Niemna, do którego doprowadzają wodę dwie rzeki: Czarna Hańcza i Szeszupa. Siedziba Suwalskiego Parku Krajobrazowego mieści się w Malesowiźnie-Turtulu, a park leży na terenie Zielonych Płuc Polski oraz wchodzi w sieć obszarów Europejskiej Sieci Ekologicznej NATURA 2000 jako Ostoja Suwalska (zob. Suwalski Park Krajobrazowy).

\section{Wyniki}

Na badanym terenie zinwentaryzowano 38 drzew z 48 wykazywanych w rejestrze Suwalskiego Parku Krajobrazowego. Znaczącą część (55,2\%) stanowiły okazy lipy drobnolistnej. Inne gatunki drzew uznanych na tym terenie za pomniki przyrody, to m.in.: klon pospolity, jesion wyniosły, świerk pospolity oraz drzewa owocowe - grusza pospolita i jabłoń pospolita. Drzewa pomniki przyrody rosły na całym obszarze parku.

Najstarszymi, ustanowionymi w 1978 r. (dwa lata po utworzeniu parku), drzewami pomnikowymi na terenie Suwalskiego Parku Krajobrazowego 
były jesion wyniosły w Szeszupce w gminie Jeleniewo oraz świerk pospolity. Pierwsze z wymienionych drzew rośnie do dzisiaj, a drugiego nie udało się odnaleźć. Ostatnie, ustanowione w 2008 r., drzewa-pomniki przyrody na tym obszarze, to trzy lipy drobnolistne w miejscowości Czajewszczyzna w gminie Jeleniewo oraz klon pospolity w Gubieniszkach również w gminie Jeleniewo. Znaczna część drzew pomnikowych została ustanowiona w latach 1990-2000 (rys. 1).

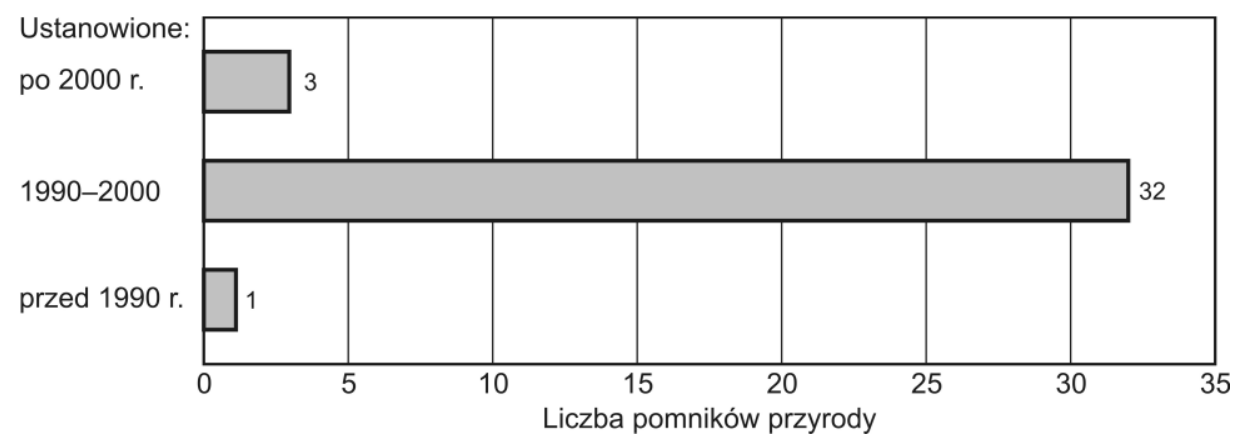

Rys. 1. Liczebność drzew-pomników przyrody na terenie Suwalskiego Parku Krajobrazowego według okresu ich ustanowienia Źródło: opracowanie własne

Najwięcej drzew uznanych za pomniki przyrody w kategorii pojedynczych drzew znajdowało się $w$ gminie Jeleniewo. $W$ granicach gminy występowała ich prawie połowa $(47,1 \%)$, najmniej z kolei odnotowano na terenie gminy Rutka-Tartak (świerk pospolity) i gminy Przerośl (klon pospolity), znajdujących się w granicach parku (tab. 2).

Prawie połowa badanych drzew (17 okazów) osiągnęła wymiary obwodu (mierzonego na wysokości $130 \mathrm{~cm}$ od powierzchni gruntu) mieszczące się w przedziale 150-250 cm. Były to: jedenaście lip drobnolistnych, trzy grusze pospolite oraz po jednym okazie świerka pospolitego, jabłoni dzikiej i klonu pospolitego. Rozmiary obwodu pnia w przedziale $250-350 \mathrm{~cm}$ osiągnęło 31,6\% badanych drzew. W grupie tej znalazły się: cztery lipy drobnolistne, pięć klonów pospolitych oraz po jednym okazie gruszy pospolitej, świerka pospolitego i jesionu pospolitego. Przeprowadzona inwentaryzacja pozwoliła na ustalenie, że największymi obwodami wyróżniały się trzy okazy lipy drobnolistnej oraz jeden dąb szypułkowy, których obwody na wysokości $130 \mathrm{~cm}$ wynosiły powyżej $350 \mathrm{~cm}$ (tab. 3). 
Tab. 2. Drzewa-pomniki przyrody na terenie Suwalskiego Parku Krajobrazowego (kategorie: pojedyncze drzewa oraz aleje)

\begin{tabular}{|c|l|c|}
\hline Lp. & \multicolumn{1}{|c|}{ Gatunek/gmina } & $\begin{array}{c}\text { Liczba drzew } \\
\text { pomnikowych }\end{array}$ \\
\hline 1 & Dąb szypułkowy (Quercus robur) - gm. Jeleniewo & 1 \\
\hline 2 & Grusza pospolita (Pyrus communis) - gm. Wiżajny & 5 \\
\hline 3 & Jabłoń dzika (Malus sylvestris) - gm. Wiżajny & 1 \\
\hline 4 & Jesion wyniosły (Fraxinus excelsior) - gm. Jeleniewo & 1 \\
\hline 5 & Klon pospolity (Acer platanoides) - gm. Jeleniewo & 1 \\
6 & Klon pospolity (Acer platanoides) - gm. Przerośl & 1 \\
7 & Klon pospolity (Acer platanoides) - gm. Wiżajny & 3 \\
\hline 8 & Lipa drobnolistna (Tilia cordata) - gm. Jeleniewo & 17 \\
9 & Lipa drobnolistna (Tilia cordata) - gm. Wiżajny & 1 \\
\hline 10 & Świerk pospolity (Picea abies) - gm. Rutka-Tartak & 1 \\
\hline 1 & Świerk pospolity (Picea abies) - gm. Wiżajny & \\
\hline
\end{tabular}

Źródło: opracowanie własne.

Tab. 3. Różnorodność gatunkowa badanych drzew-pomników przyrody na terenie Suwalskiego Parku Krajobrazowego

\begin{tabular}{|l|c|c|c|c|c|}
\hline \multirow{2}{*}{ Gatunek drzewa } & \multicolumn{3}{|c|}{ Obwód (cm) na wysokości $130 \mathrm{~cm}^{*}$} & \multirow{2}{*}{ Razem } \\
\cline { 2 - 6 } & $50-150$ & $150-250$ & $250-350$ & $>350$ & \\
\hline Lipa drobnolistna (Tilia cordata) & 3 & 11 & 4 & 3 & 21 \\
\hline Klon pospolity (Acer platanoides) & 1 & 1 & 5 & - & 7 \\
\hline Grusza pospolita (Pyrus communis) & 1 & 3 & 1 & - & 5 \\
\hline Świerk pospolity (Picea abies) & - & 1 & 1 & - & 2 \\
\hline Jabłoń dzika (Malus sylvestris) & - & 1 & - & - & 1 \\
\hline Dąb szypułkowy (Quercus robur) & - & - & - & 1 & 1 \\
\hline Jesion pospolity (Fraxinus excelsior) & - & - & 1 & - & 1 \\
\hline Razem & 5 & 17 & 12 & 4 & 38 \\
\hline
\end{tabular}

* Mierzony na wysokości $130 \mathrm{~cm}$ od powierzchni gruntu.

Źródło: opracowanie własne.

Średnie obwody drzew uznanych za pomniki przyrody na terenie Suwalskiego Parku Krajobrazowego zaprezentowano w tab. 4. Wysokość badanych drzew wahała się od 12 do $30 \mathrm{~m}$ w kategorii pojedynczych drzew oraz od 13 do $36 \mathrm{~m} \mathrm{w}$ badanej alei (aleja lipowo-klonowa w miejscowości Stara Hańcza w gm. Wiżajny). Najwyższym drzewem okazał się świerk pospolity (o wysokości $30 \mathrm{~m}$ ) rosnący w miejscowości Jaczne na terenie gminy Rutka-Tartak, przy ścieżce wokół jeziora Jaczno. Wiele drzew pomnikowych nie posiadało już tabliczek, którymi oznacza się uznane za pomniki 
przyrody okazy. Prawdopodobnie od czasu ustanowienia nie podlegały już monitoringowi. Oznakowania nie posiadało ponad $80 \% \mathrm{z}$ badanych drzew. Tabliczki widniały tylko na 10 okazach.

Tab. 4. Średnie obwody i wysokości badanych drzew pomnikowych w Suwalskim Parku Krajobrazowym

\begin{tabular}{|l|c|c|}
\hline \multicolumn{1}{|c|}{ Kategoria drzew pomnikowych } & $\begin{array}{c}\text { Średni } \\
\text { obwód w cm }\end{array}$ & $\begin{array}{c}\text { Średnia } \\
\text { wysokość w m }\end{array}$ \\
\hline \multicolumn{1}{|c|}{ Pojedyncze drzewo } \\
\hline Dąb szypułkowy* (Quercus robur) & 374 & 21 \\
\hline Grusza pospolita (Pyrus communis) & 197 & 14 \\
\hline Jabłoń dzika* (Malus sylvestris) & 159 & 15 \\
\hline Jesion wyniosły* (Fraxinus excelsior) & 292 & 13 \\
\hline Klon pospolity (Acer platanoides) & 331 & 21 \\
\hline Lipa drobnolistna (Tilia cordata) & 372 & 25 \\
\hline Świerk pospolity (Picea abies) & 265 & 28 \\
\hline \multicolumn{1}{|c|}{ Aleja drzew } \\
\hline Lipa drobnolistna (Tilia cordata) & 215 & 27 \\
\hline Klon pospolity (Acer platanoides) & 262 & 31 \\
\hline
\end{tabular}

* Pojedyncze okazy.

Źródło: opracowanie własne.

Drzewa-pomniki przyrody identyfikowano często w trudno dostępnych miejscach. Niektóre rosły na prywatnych działkach, co również bardzo utrudniało ich odnalezienie. Podczas inwentaryzacji nie udało się odszukać czterech drzew, pierwotnie uznanych za pomniki przyrody, a prawdopodobnie już nieistniejących. Były to dwie grusze pospolite oraz dwa klony pospolite widniejące $\mathrm{w}$ rejestrach pomników przyrody SPK. Podobnie $\mathrm{w}$ alei lipowej okazało się, że dwa drzewa już nie istnieją - zlokalizowano jeden pień, a drugiego nie odnaleziono. Wśród zinwentaryzowanych okazów można wskazać te, które - zgodnie z prawną definicją pomnika przyrody - wyróżniają się spośród innych tworów przyrody żywej cechami dendrometrycznymi, walorami historycznymi czy krajobrazowymi bądź znaczeniem przyrodniczym. Informacje o tego typu okazach należałoby upowszechnić przede wszystkim w lokalnych wydawnictwach turystycznych i popularnonaukowych, choć trudno stwierdzić, czy mogą stanowić atrakcję turystyczną, szczególnie że trudno je odnaleźć w terenie.

Okazy pomnikowe drzew znajdujących się w Suwalskim Parku Krajobrazowym proponuje się wykorzystać w lokalnych działaniach w zakresie turystyki i edukacji, m.in. poprzez: 
A. Włączenie drzew pomnikowych do ścieżki poznawczej „Na Górę Zamkową" - stworzenie questingu lub gry terenowej.

Obecnie wiedzę dotyczącą Góry Zamkowej możemy zdobywać dzięki pokonaniu ścieżki poznawczej „Na Górę Zamkową” (6 km), uzupełnionej trasą turystyczną nazwaną „Tropem Sziurpy” (3,2 km), oraz poprzez zwiedzenie powstałej w 2014 r. Izby Pamięci Jaćwieskiej. Na terenie Góry Zamkowej rosną trzy drzewa-pomniki przyrody, ustanowione w 2008 r. Są to dwie lipy drobnolistne znajdujące się na południowo-wschodnim stoku oraz trzecia przy samym wierzchołku góry. Pomimo bliskiej obecności szlaku prowadzącego na szczyt wzgórza, drzewa nie zostały uwzględnione w programach ścieżek edukacyjnych. Przy brzegu jeziora Kluczysko, gdzie przebiegają obecnie ścieżki, znajduje się świerk pospolity o obwodzie $230 \mathrm{~cm}$ i wysokości $40 \mathrm{~m}$.

B. Wykorzystanie drzew-pomników przyrody, rosnących na terenie dawnej osady jaćwieskiej w Szurpiłach, w działalności edukacyjnej.

Obecność okazów pomnikowych w sercu dawnego osadnictwa Jaćwingów oraz istnienie legendy o Żaltisie umożliwiają nadanie tym okolicom mistycznego charakteru. Poprzez stworzenie miejsc opisanych w legendzie możliwe jest więc przypomnienie historii związanej z przygraniczną kulturą Suwalszczyzny i Litwy.

C. Upowszechnienie informacji o drzewach-pomnikach przyrody na terenie Suwalskiego Parku Krajobrazowego.

Pomnikowe okazy drzew warto udostępnić szerszej publiczności. Obecnie żadne z wymienionych wcześniej drzew nie są oznaczone tabliczką, a przy alei lipowej znajduje się jedynie zawierająca jej opis tablica edukacyjna. W alei lipowej znajdują się dwie lipy drobnolistne, charakteryzujące się wyjątkowym kształtem pnia, co może zainteresować odwiedzających ten teren. Włączenia drzew-pomników przyrody do ścieżki poznawczej w celu ich upowszechnienia należałoby jednak dokonać poprzez m.in.:

- nadanie poszczególnym drzewom oraz rosnącym w alei lipowej imion byłych właścicieli dworu Stara Hańcza;

- zainstalowanie tablic opisujących najważniejsze wydarzenia historyczne lub właścicieli związanych z dawną posiadłością.

Zaproponowane lokalnym władzom działania pokazują, jak można wykorzystać okazy drzew-pomników przyrody w celu zaprezentowania w ciekawy sposób historii Suwalskiego Parku Krajobrazowego. Dzięki temu takie obiekty przyrody ożywionej stosunkowo niewielkim kosztem podwyższyłyby atrakcyjność turystyczną i edukacyjną tego terenu, przyciągając większą liczbę turystów. 


\section{Dyskusja}

Wprowadzenie ochrony przyrody ożywionej i nieożywionej w postaci ustanowienia drzew pomnikowych powinno istotnie przeciwdziałać zagrożeniom określonych okazów, np. gospodarczemu pozyskiwaniu drzew w cennym starodrzewie, osuszaniu torfowisk lub terenów do nich przylegających, czy też wprowadzaniu gatunków obcych do ekosystemu.

Wykonanie zabiegów ochronnych cennych okazów powinno się rozpocząć od uzupełnienia $\mathrm{w}$ wielu przypadkach tabliczek świadczących o tym, że określone drzewa zostały uznane za pomniki przyrody. Godło w wielu pomnikach jest też nieaktualne lub niezgodne $\mathrm{z}$ dzisiejszym. Oznacza to, że nawet jeśli tabliczki widnieją na okazach, to są nieprawidłowe. Niejednokrotnie numery na drzewach nie zgadzają się ze stanem faktycznym, co przecież jest łatwe do wyeliminowania. Dokonania uzupełnień oraz wymiany nieaktualnych oznaczeń na drzewach-pomnikach przyrody powinno się przeprowadzić po dokładnej wcześniejszej inwentaryzacji.

Gminy oraz starostwa powiatowe, poprzez odpowiednie referaty mające kompetencje w tym zakresie, powinny dbać o swoje wizytówki, jakimi bez wątpienia są drzewa pomnikowe, a przede wszystkim dostrzegać dotykające je problemy. Tymczasem często zapomina się o tego typu pomnikach przyrody po ich ustanowieniu. Sama idea ich utworzenia jest uzasadniona, lecz to nie wystarcza. Dużym problemem jest brak prac konserwatorskich związanych z tymi drzewami, choćby w przypadkach złamania konarów przez czynniki abiotyczne, takie jak wiatr. Należy pamiętać, że dbanie o lokalne dobro przyrodnicze to podstawa do wykorzystywania go w planach rozwoju turystyki, m.in. również w oparciu o pomnik przyrody.

\section{Podsumowanie}

Główne cele i przyczyny ochrony drzew pomnikowych to przede wszystkim ochrona drzew jako zabytków przyrody i równocześnie kultury, ale także ochrona drzew ze względów historycznych (drzewa $\mathrm{w}$ miejscach związanych $\mathrm{z}$ wydarzeniami historycznymi, kulturowymi, legendami czy podaniami ludowymi), lub też ochrona drzew jako obiektów naukowych oraz ekologicznych. 
Okazy drzew-pomników przyrody stanowią na terenie Suwalskiego Parku Krajobrazowego niedocenianą część lokalnej przyrody. Wiedzę o tych okazach warto upowszechniać $\mathrm{w}$ taki sposób, aby społeczeństwo dostrzegało na obszarze swojej małej ojczyzny przykłady form ochrony przyrody, jakimi są pomniki przyrody. $W$ czasach, w których ogromne znaczenie ma edukacja przyrodniczoleśna, należałoby upowszechniać i pielęgnować wiedzę o najcenniejszych historycznych okazach drzew. Wielokrotnie można byłoby uczynić z nich lokalne atrakcje turystyczne. Okoliczne szkoły $\mathrm{w}$ ramach zajęć przyrodniczych mogłyby poświęcić oddzielne lekcje, aby temat ochrony drzew był przedstawiany dzieciom i młodzieży. Jeżeli młodzi ludzie będą odpowiednio wyedukowani, to informacje o lokalnych formach ochrony przyrody dotrą również do dorosłych. Zaowocowałoby to nie tylko wiedzą, ale przede wszystkim większym szacunkiem do przyrody i lokalnej historii, wiążąc mieszkańców silniej z regionem.

Pomnik przyrody jest kategorią prawną, oznaczającą objęcie tworu przyrody ścisłą (zupełną, pełną) ochroną prawną, z określonymi konsekwencjami za jej nieprzestrzeganie. Istotą tej ochrony jest całkowite wyłączenie chronionej rośliny spod oddziaływania na nią człowieka w sensie jej gospodarczego użytkowania. Jest to jednoznaczne z nadaniem drzewu statusu nienaruszalności (por. Siewniak, 1998), a więc znamienia ochrony biernej. Oczywiście w przypadku drzew-pomników takie działania są niewystarczające. Takie okazy wymagają zapewnienia stałej, aktywnej, szerokiej i systematycznej pielęgnacji. Utrzymanie pomnika przyrody oznacza zachowanie drzewa w całości i zapewnienie mu koniecznych warunków siedliskowych. Dzięki prawidłowej pielęgnacji wiele drzew pomnikowych doznało wsparcia i znajduje się we względnie dobrym stanie. W trudnych warunkach środowiskowych drzewa-pomniki przyrody wymagają dodatkowo ograniczenia do minimum wszelkiego potencjalnego wpływu czynników szkodliwych. Jednocześnie w warunkach miejskich czy na obszarach komunikacyjnych na zarządzających tym zasobem spoczywa obowiązek zapewnienia maksymalnego bezpieczeństwa życiu i mieniu ludzi.

Popularność pomnikowych drzew na terenie Suwalskiego Parku Krajobrazowego jest zróżnicowana. Wskazane byłyby działania popularyzujące pomnikowe okazy drzew jako atrakcje turystyczne, m.in. poprzez promocję w katalogach, folderach gmin oraz powiatów, jak również umieszczenie w programach wycieczek tych osobliwości natury. Równie ważne byłyby informacje $\mathrm{w}$ materiałach promocyjnych gospodarstw agroturystycznych, dotyczące występowania w ich pobliżu tego typu okazów. 
Należy podkreślić jednak fakt, że pojedyncze egzemplarze drzew uznanych za pomniki przyrody mogą okazać się walorem o niedostatecznej sile przyciągania turystów, ale powinny być wykorzystywane jako jeden ze składników rozszerzonego produktu turystycznego.

\section{Bibliografia}

Constaza, R., d'Arge, R., de Groot, R., Farberk, S., Grasso, M., Hannon B., Limburg, K., Naeem, S., O'Neill, R.V., Paruelo, J., Raskin, R.G., Suttonkk, P., van den Belt, M. (1997). The value of the world's easystem services and natural capital. Nature, 387, 253-260.

Grzywacz, A. (2001). Drzewa - pomniki przyrody świata i Polski. Agricola, 51, 29-41.

Grzywacz, A., Pietrzak, J. (2013). Drzewa - pomniki przyrody. Warszawa: Polskie Towarzystwo Leśne.

Grzywacz, A. (2011). Drzewa jako obiekty kulturowe. Studia i Materiaty CEPL w Rogowie, $13(4 / 29), 45-62$.

Kasprzak, K. (2005). Ochrona pomników przyrody. Zasady postępowania administracyjnego. Poznań: Wydawnictwo ABRYS.

Kaszyński, B., Szczukowska, H. (2013). Pomniki przyrody jako istotny element edukacji ekologicznej w Bydgoszczy. Studia i Materiaty CEPL w Rogowie, 15 (37/4), 157-161.

Korczyński, M. (2004). Walory edukacyjne starych parków. W: M. Wojtysiak (red.). Człowiek $i$ środowisko. Barcin: Stowarzyszenie Ekologiczne w Barcinie.

Kosmala, M. (2005). Po co ludziom drzewa, czyli o roli znaczeniu drzew w życiu człowieka. W: E. Oleksiejuk, J. Piotrowiak (red.), Zieleń miejska - naturalne bogactwo miasta. Zasady gospodarowania i ochrona (s. 75-88). Torun: Polskie Zrzeszenie Inżynierów i Techników Sanitarnych Oddział Toruń.

Rozporzadzenie Ministra Środowiska z dnia 4 grudnia 2017 r. w sprawie kryteriów uznawania tworów przyrody żywej i nieożywionej za pomniki przyrody. DzU 2017, poz. 2300.

Siewniak, M. (1998). Ochrona drzew pomnikowych. Komunikaty Dendrologiczne, 7, 3-15.

Staniewska-Zątek, W. (2007). Turystyka a przyroda i jej ochrona. Poznań: Wydawnictwo Naukowe Bogucki.

Suwalski Park Krajobrazowy. Pobrane z: http:/ / www.spk.org.pl (20.12.2018).

Ustawa o ochronie przyrody z dnia 16 kwietnia 2004 r. DzU 2004, nr 92, poz. 880.

Podziękowania

Autorzy sktadaja podziękowania

Dyrekcji Suwalskiego Parku Krajobrazowego oraz Członkom Koła Naukowego Leśników

Zamiejscowego Wydziału Leśnego Politechniki Białostockiej w Hajnówce za pomoc w realizacji badań terenowych. 


\title{
DRZEWA-POMNIKI PRZYRODY \\ NA TERENIE SUWALSKIEGO PARKU KRAJOBRAZOWEGO
}

\begin{abstract}
Abstrakt: Celem badań członków Studenckiego Koła Naukowego Leśników Politechniki Białostockiej była aktualizacja informacji o drzewach uznanych za pomniki przyrody na terenie Suwalskiego Parku Krajobrazowego. Zakres prac obejmował również określenie ich stanu ochrony oraz ukazanie możliwości wykorzystania tych okazów jako atrakcji turystycznych. Wyniki badań wykazały, że drzewa ustanowione jako pomniki przyrody są w niektórych przypadkach trudne do odnalezienia w terenie. Popularność pomnikowych drzew jako obiektów turystycznych jest zróżnicowana. Drzewa jako elementy naturalnego krajobrazu wśród bogactwa zasobów przyrodniczych mogą stać się podstawą rozwoju turystyki edukacyjnej. Wydaje się jednak, że mogą one stanowić uzupełnienie rozbudowanego produktu turystycznego na tego typu obszarach.
\end{abstract}

Słowa kluczowe: Suwalski Park Krajobrazowy, pomnik przyrody, przyroda Polski Wschodniej, drzewo-pomnik przyrody.

\section{TREES - NATURAL MONUMENTS IN THE SUWAŁKI LANDSCAPE PARK}

\begin{abstract}
The aim of the research was to update information and inventory of trees recognized as natural monuments in the Suwałki Landscape Park. The scope of work also included determining their protection status. The research results showed that trees considered as natural monuments are in some cases difficult to find, often they do not have signs. However, they are the potential to use them as tourist attractions, especially in the areas of landscape parks. An important issue is the distinction of specimens and objects that stand out among other natural creations.
\end{abstract}

Keywords: Suwałki Landscape Park, natural monument, nature of Eastern Poland, tree - natural monument. 